\title{
Minimum wage and employment: a gender perspective for Mauritius
}

Minimum wage and employment

\author{
Varuna Dreepaul-Dabee and Verena Tandrayen-Ragoobur \\ Faculty of Social Sciences and Humanities, University of Mauritius, Reduit, Mauritius
}

\begin{abstract}
Purpose - This paper aims to examine the employment effect of the minimum wage in Mauritius, a country that has recently introduced an economy-wide national minimum wage. As women have low labor force participation rate and higher unemployment rate compared to men, this study sheds light on the impact of the national minimum wage on male and female employment.

Design/methodology/approach - A conceptual framework based on the labor-leisure model of Blundell et al. (2007) incorporating the minimum wage as an important variable influencing the employment decision of the individual serves as the methodological backdrop of this paper. It applies the difference-in-difference estimation technique and uses micro data from the Continuous Multi-Purpose Household Survey for the period 2017-2019.

Findings - The results show that minimum wage has a significant negative impact on overall employment. With the imposition of the national minimum wage, the probability that an individual, currently earning less than the minimum wage, remains employed is 0.525 lower than that of a worker earning above the minimum wage level. Moreover, using sex-disaggregated data, the analysis demonstrates the negative employment effects of the minimum wage adversely impact women more than men.

Originality/value - This is a first attempt to estimate the effect of the newly introduced national minimum wage on employment in Mauritius. While the effects of a minimum wage vary across different segments of the economy, this study adopts a gender perspective by comparing the impact of the minimum wage on male and female employment.
\end{abstract}

Keywords Minimum wage, Employment, Gender

Paper type Research paper

\section{Introduction}

Globalization has profound effects on the labor market in terms of expanding job opportunities as well as boosting real wages. While many developed countries have reaped the benefits of global integration, developing countries are still struggling to improve their labor market conditions and reduce poverty. In view of reducing wage inequality and improve livelihoods of workers, many developing economies are introducing or increasing their national minimum wage, which aims to protect workers at the lowest end of the wage spectrum, who are either less educated or low skilled or both.

The empirical evidence assessing the impact of minimum wage on employment remains inconclusive across both developed and developing countries. The standard neoclassical theory predicts that under perfect competition, an increase in minimum wage above market clearing rates will lead to unemployment (Zucker, 1973; Carter, 1978; Clemens and Wither, 2019; Kawaguchi and Mori, 2021). However, Card (1992), Card and Krueguer (1994),

\section{JEL Classification - J16, E24}

(C) Varuna Dreepaul-Dabee and Verena Tandrayen-Ragoobur. Published in Journal of Business and Socio-economic Development. Published by Emerald Publishing Limited. This article is published under the Creative Commons Attribution (CC BY 4.0) licence. Anyone may reproduce, distribute, translate and create derivative works of this article (for both commercial and non-commercial purposes), subject to full attribution to the original publication and authors. The full terms of this licence may be seen at http:// creativecommons.org/licences/by/4.0/legalcode.

Funding: The authors acknowledge funding received from Higher Education Commission, Mauritius.

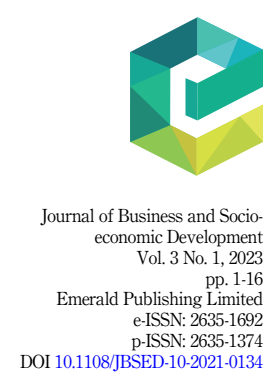

Received 7 October 2021 Revised 13 November 2021 6 January 2022

Accepted 25 January 2022 (1) 
JBSED 3,1

2

Stewart (2004) and Bonin et al. (2019) showed that minimum wage increases may not necessarily harm employment. This line of research triggered a reassessment of the existing underlying minimum wage theory to reconcile the conflicting results. For instance, Schmitz (2017) analyzed the introduction of statutory national minimum wage on employment in Germany and reveals that minimum wage has considerable negative effects on employment, whereas Bonin et al. (2019) undertook a similar analysis that demonstrates that the minimum wage has no statistically significant effect on employment in Germany.

There is extensive empirical literature on the employment effects of minimum wage. However, it is more focused on developed countries, with only a few recent studies on developing countries, with mixed results. For example, Neumark and Corella (2020) observed that minimum wage exerted substantial negative effects on employment in developing countries, but Wang and Gunderson (2018) concluded that minimum wage did not impart any adverse effect on employment of low-skilled individual in China. In particular, studies related to Africa are relatively scant. Andalón and Pagés (2008) assessed the effect of minimum wage legislation in Kenya and observed that an increase in the minimum wage was associated with a decline in the share of formal employment and increase in self-employment. By contrast, Asmal et al. (2018) analyzed the employment effect of minimum wage in Mauritius by considering various remuneration orders for the years 2004-2014 on employment and concluded that minimum wage had a marginal positive effect on employment in the covered sector, with an estimated employment elasticity of 0.113 .

Since its independence, Mauritius has witnessed effective economic development grounded on a well-functioning market economy and a democratic political system. The country has achieved high rankings in several global indices; for instance, it ranks first in Africa and 13th out of 190 countries in the ease-of-doing business (World Bank, 2020). Moreover, in terms of overall effective governance in Africa, Mauritius has been maintaining its first position. Further, less than 1\% of the population lives on less than US $\$ 1.25$ per day (PPP) and the proportion of households below the relative poverty line, set at half of median household income per adult equivalent, has remained steady at $9.4 \%$ since 2012 (Statistics Mauritius, 2018). The Gini coefficient decreased from 0.414 to 0.400 from 2012 to 2017, indicating of an improvement in income equality (Statistics Mauritius, 2018).

Though Mauritius has made significant progress on the economic front, unemployment remains a major challenge. In 2019, the Mauritian labor force numbered 591,000, and the overall unemployment rate stood at $7.2 \%$. In the same year, female unemployment $(11.1 \%)$ substantially exceeded male unemployment (4.9\%) (Statistics Mauritius (2020a). Apart from their being more numerous among the ranks of the unemployed, women earn an average monthly income (US\$1,131) appreciably lower than that enjoyed by men (US\$1,486) (Statistics Mauritius, 2020b). During the year 2017, about 7\% of workers took home, a salary less than US\$474 (National Wage Consultative Council, 2017). With the salutary aim of raising incomes of low-wage workers and improving their standards of living, irrespective of gender, the national minimum wage was introduced in 2018. Notably, this study attempts to assess the gender effects of the introduction of the national minimum wage on employment in Mauritius.

Previously, there was neither a single wage system in Mauritius nor a common minimum wage for various occupations across sectors. In Mauritius, wage setting, in terms of institutional mechanism, is dual: the Pay Research Bureau (PRB) establishes wages in the public sector, while the National Remuneration Board (NRB) sets wages for the private sector through remuneration orders. In its attempt to reduce wage inequality and poverty, as well as to improve the livelihoods of workers, the authorities introduced a nationwide statutory minimum wage of US\$503 (MUR8,500) that spans to all sectors of the economy in the year 2018. Although the statutory minimum wage applies to all employees aged over 16 years, the threshold level varies for some categories of workers; for instance, in Export 
Processing Zone, the monthly minimum wage is US\$473. Likewise, workers on accredited training, or on apprenticeship, with no job experience, are entitled a monthly salary of just US $\$ 463$.

To the best of our knowledge, scholarly discussion of the employment effects of the minimum wage on employment is very scant for Mauritius. Asmal et al. (2018) focused almost exclusively on the implications on employment of remuneration orders effectuated prior to the imposition of the national minimum wage in Mauritius. The intellectual contribution of this paper to the literature on the macro-economic effects of the minimum wage on employment is threefold. First, it develops a conceptual framework extending the laborleisure model of Blundell et al. (2007) by incorporating minimum wage as an important variable influencing employment. In the backdrop of this conceptual model, second, the paper, using the difference-in-difference (DiD) method, sheds light on the direct impact of the national minimum wage on overall employment. Mauritius serves as a case study of the employment effects of the imposition of the national minimum wage in a resource-scarce economy where the only available resource is human capital. Third, the paper adopts a gender perspective by probing into the impact of the minimum wage on male and female employment.

This paper is structured as follows: Section 2 reviews the existing theoretical and empirical literature and explains the conceptual framework. Section 3 sets out the data and methodology used. Section 4 analyzes the findings, and we finally conclude in Section 5 with relevant policy implications.

\section{Literature survey}

The employment effects of the minimum wage have stimulated a vast body of academic literature (Schmitt, 2013). The neoclassical theory predicts that under perfect competition, an increase in minimum wage above market clearing rates will lead to unemployment. While in other labor market conditions like monopsony, the employer has market power in employing a particular type of labor and can hold the price of labor at low levels. In the presence of a minimum wage, the firm is compelled to pay the legally bounded minimum wage and incurs higher labor costs.

Recently concluded research has reopened the debate about the appropriate theoretical description of the labor market, with some of the empirical research rejecting the competitive model in favor of other formulations incorporating efficiency wage theory or the job search model (Basu and Felkey, 2009; Ahn et al., 2011; Walsh, 2012). In the efficiency wage theory, Rebitzer and Taylor (1995) advanced that increase in minimum wage will reduce the relative attractiveness of jobs that are paid slightly above the minimum wage and render jobs that were formerly paid below the minimum relatively more attractive. Therefore, increase in wages above the minimum wage acts as an instrument to increase the scope for selection, to reduce shirking as well as labor turnover and to improve morale and discipline. In addition, in the job search theory, Burdett and Mortensen (1998) assumed that workers do not have perfect information about all potential job opportunities in the labor market, and acceptance or rejection of job offers are made by individuals acting in isolation.

Seminal empirical works like Katz and Krueger (1992) advanced the proposition that increases in the federal minimum wage in Texas has led to increase in employment in those firms likely to have been most affected by increases in minimum wage. These findings were further supported by Card and Krueguer (1994) who demonstrated that the restaurants affected by the minimum wage in New Jersey increased their employment. However, Neumark and Wascher (1995a), using the DiD technique on payroll data, found opposite results with a statistically significant negative relationship between minimum wage and employment.
Minimum

wage and employment 
JBSED

3,1

4

It is axiomatic that low-wage sectors of the economy are more affected by the minimum wage than high-wage sectors. Machin et al. (2003) studied the effect of the minimum wage on wages and employment in the residential home care industry in the UK and observed that minimum wage, while increasing the wages of a large number of care home workers, reduced employment. In the same line of thought, Stewart (2004), applying DiD techniques, analyzed the effect of the introduction of minimum wage on employment across four demographic groups: adult men and women as well as young men and women. The latter observed the absence of any significant adverse employment effect in the UK which is in contradiction to the result of Machin et al. (2003), whose study, albeit, focused on the domestic care sector. However, Sturn (2018) found little evidence on the effects of minimum wage rates on employment of female low-skilled workers. With the imposition of the 2015 national minimum wage in Germany, Schmitz (2017) indicated that minimum wage has had considerable negative effects on employment. Similar findings had also been obtained by Caliendoa et al. (2018), who examined the short-term employment effects of the newly introduced minimum wage in Germany. However, Bonin et al. (2019) examined the employment effects of the introduction of German statutory minimum wage and demonstrated that there was no statistically significant effect on regular employment.

Across developed nations, the campaign for a minimum wage has been growing and, recently, it has started to proliferate among developing countries - in turn, eliciting academic research activity on the effects of the minimum wage in various developing countries. For instance, Gindling and Terrell (2009) observed that higher minimum wage may increase unemployment in Honduras. Further, Del Carpio et al. (2015) indicated that the employment effects of minimum wage hikes were negative, and these effects were more pronounced among small firms and for less-educated employees and female workers. Fang and Lin (2015) used country-level minimum wage data combined with urban household survey microdataset to re-evaluate the employment effects of minimum wage changes in China from 2002 to 2009. Their results showed that minimum wage changes led to significant adverse effects on employment in the Eastern and Central regions of China - with negative employment effects dispersed across women, young adults and low-skilled workers.

Incipient empirical studies on Africa can be traced back to Bhorat et al. (2014) who, using the DiD model, analyzed the impact of the introduction of a minimum wage law within the agricultural sector in South Africa for the period 2000 to 2007. These results suggest that there is a significant reduction in employment in the agriculture sector but no significant change in hours of work following the introduction of the minimum wage.

From the above brief survey of the literature, it is evident that, while studies relating to the employment effect of minimum wage are legion, but no consensus, across both developed and developing countries can be identified in terms of that effect. Thus, this study aims to provide additional perspective on that effect from the side of a small, resource-poor developing nation, Mauritius.

\section{Conceptual framework}

The conceptual framework is derived from the neoclassical labor-leisure model of Blundell et al. (2007) where the individual maximizes utility subject to time and wage constraints. Assuming that a rational individual has a utility function $U(C, L)$, where $C$ represents consumption of goods measured in a monetary unit and $L$ represents leisure hours. The higher the level of $\mathrm{U}$, the greater is the satisfaction of the individual. We assume that buying more goods or having more leisure hours both increase the person's utility, and $C$ and $L$ are "goods," not "bads."

The partial derivatives of the utility function are $U_{c}=\frac{\partial U}{\partial C}>0$ and $U_{L}=\frac{\partial U}{\partial l}>0$. 
The individual faces a budget constraint, which comprises of time factor and wages, and this is represented as:

$$
C=w(T-L)+V
$$

Minimum

wage and employment

where:

$T$ - total hours available in the time period under analysis (and assumed constant);

$w$ - wage rate; and

$V$ - other income.

Rewriting equation (1) with wages on the left hand side:

$$
c+w L=w T+V
$$

The individual's full income is given by $w T+V$ and represents how much money the individual would have if he or she were to work every available hour. Full income is spent either on consumption or on leisure. The budget constraint shows that each hour of leisure requires the expenditure of $w$ monetary units. Hence, the price of leisure is $w$.

Thus, the individual maximizes utility subject to the budget constraint:

The Lagrangian function is set up as follows:

$$
\operatorname{Max} \Omega=U(C, L)+\lambda(w T+V-C-w L)
$$

The first-order conditions are as follows:

$$
\begin{gathered}
\frac{\partial \Omega}{\partial C}=U_{c}-\lambda=0 \\
\frac{\partial \Omega}{\partial L}=U_{l}-\lambda w=0 \\
\frac{\partial \Omega}{\partial \lambda}=w T+V-C-w L=0
\end{gathered}
$$

By solving equations (4) and (5), the wage rate is equal to the ratio of the marginal utilities, which are affected by age, sex, education level, marital status, leisure and income.

$$
\begin{gathered}
w=\frac{U_{l}}{U_{c}} \\
w T+V-C-w L=0 \\
L=\frac{w T+V-C}{w}
\end{gathered}
$$

Equation (8) shows that labor is dependent on wage rate, which is affected by age, sex, education level, marital status, leisure and income. Neumark and Wascher (1995b) points out that utility may be influenced by other factors such as age, sex, work experience, family size and family income, as reflected in equation (9). Therefore, utility is the dependent variable estimated on a set of explanatory variables $X$, which considers both individual- and sectorwise dimensions:

$$
U_{k t}^{j}=\beta_{0}+M W_{k, t}^{j} \beta_{j}+X_{k, t}^{j} \lambda_{j}+\varepsilon_{k t}^{j}
$$


JBSED

3,1

6

$U_{i k t}^{j}-$ employment activity for individual i;

$M W_{k, t}^{j} \beta_{j}$ - minimum wage;

$X_{k, t}^{j} \lambda_{j}$ - the vector of individual characteristics (age, sex, education level, marital status, leisure and income); and

$\varepsilon_{k t}^{j}$ - error term.

Therefore, the explicit model predicting the probability of being employed will be given as:

$$
\ln (l)=\ln \left(\beta_{0}+M W_{k, t}^{j} \beta_{j}+X_{k, t}^{j} \lambda_{j}+Z_{k, t}^{j} \alpha_{j}+\varepsilon_{k t}^{j}\right)
$$

Equation (10) assumes that an individual chooses among a series of alternatives, with each choice being subject to both endogenous and exogenous variables and other individualspecific unobserved effects. It shows that the labor hours are a function of minimum wages and other control variables such as age, sex, education level, marital status, leisure and income.

\section{Data and methodology}

\subsection{Data source}

This study uses micro data from the Continuous Multi-Purpose Household Survey (CMPHS) of 2017-2019. The CMPHS is a monthly survey and provides statistical information on the social and economic characteristics of the population of the Republic of Mauritius. It is a nationally representative survey that covers 12,000 households and 40,000 individuals each year and contains detailed information on individual and household characteristics, including a detailed labor market module. For this study, information on employment is drawn from the labor force component for working age individuals. The survey has a rotating panel structure, and the individuals are interviewed face-to-face, four times, over a period of two years.

The same individuals have been selected and matched over a period of two years. The household is grouped in various rotations, and the same household is interviewed four times over two years. In some cases, where the individual dies or the household has shifted to another area, it is replaced by a new household. To ensure that the same initial household is chosen in the same rotation in each period, the new household is removed in the initial sample. The households are assigned a unique household number in the same rotation group, and then the households and the details of the individuals are matched from the first period to the next period. The demographic characteristics of these individuals are observed from September 2017 to March 2019. As the minimum legal working age in Mauritius is 16 years, individuals aged between 16 and 65 years are selected from the matched sample of household for the analysis.

\subsection{Difference-in-difference estimation}

The DiD estimation is used to approximate the effects of specific policy interventions that have differential impacts on varied segments of the population. Time is an important factor, and individuals are considered in two time periods, $t=0$ and 1 , where 0 indicates a time period before the policy intervention, i.e. pre-treatment, and 1 indicates a time period after the intervention period, i.e. post-treatment. There are two groups of individuals, namely, the "control group," which consists of individuals who are not affected by the policy change and remain untreated at the two different points in time, whereas a "treatment group" refers to the group that received the treatment and then is treated at the second period. 
With the introduction of the minimum wage at the beginning of 2018, a sharp rise in wages is expected, especially for those individuals who are at the bottom of the wage spectrum. The starting point of the DiD technique is that, other things being equal, it is expected that the group of workers whose wages were raised to comply with the new minimum wage will be more affected than the group at the higher end of the wage spectrum. Workers whose incomes were raised with the introduction of minimum wage become the treatment group, and those workers whose incomes already exceeded the minimum wage threshold form part of the control group. These two groups cannot be directly compared as the identification of any casual effect or observation would not be possible because, even in the absence of the minimum wage, the workers at the lower end of the wage spectrum demonstrate lower probabilities of employment. Thus, within the DiD framework, the difference between the two groups after and before the introduction of minimum wage is compared.

A simple DID regression is illustrated below where $y$ is the outcome:

$$
\left.\left.y=\beta_{0}+\beta_{1}(\text { Treatment })+\beta_{2} \text { (Time }\right)+\beta_{3} \delta \text { (Time } * \text { Treatment }\right)+\varepsilon_{i}
$$

where:

$\beta_{0}-$ constant term;

$\beta_{1}$ - treatment group specific effect (to account for average permanent differences between treatment and control before the intervention);

$\beta_{2}$ - time trend in the control group;

$\beta_{3}-$ true effect of treatment (DiD estimate); AND

$\varepsilon_{i}-$ error term.

Based on the conceptual framework, the same methodology espoused by Card (1992) and Neumark and Wascher (1995a) is used in the current study to estimate the employment effects of minimum wage. This is as follows:

$$
E_{i t}=\alpha+\beta_{1} M W_{i t}+\beta_{2} X_{i t}+\theta_{i}+\tau_{t}+\varepsilon_{i t},
$$

where $E_{i t}$ is the main dependent variable, which indicates whether the individual is employed in the survey year. The key independent variable is $M W_{i t}$, which represents the minimum wage, and $\beta_{1}$ is the key parameter of interest, the $\mathrm{DiD}$ estimator. $\theta_{i}$ represents the timeinvariant factor that captures any unmeasured differences in individuals that are fixed across time, and $\tau_{t}$ captures a time trend common to all individuals. Table 1 summarizes the variables used in the regression analysis.

\section{Findings and discussions}

\subsection{Minimum wage effect on overall employment}

Table 2 shows the means of the key variables before and after the introduction of the national minimum wage. The treatment group includes individuals who were earning less than the minimum wage whose income increased following the intervention, whereas the control group consists of workers who were already earning more than the minimum wage. The variable employed indicates whether the individual was working at the time of the survey and takes a value of 1 if he or she was working, or else 0 . The table below shows that the mean of people who were working and earning less than the minimum wage threshold of MUR 8,500 (treatment group) has reduced from 0.9 to 0.4 , whereas the mean of the control group has seen a slight increase from 0.4 to 0.5 . This indicates that more people are benefitting from 


\begin{tabular}{|c|c|c|c|}
\hline $\begin{array}{l}\text { JBSED } \\
3,1\end{array}$ & Variables & Description & $\begin{array}{l}\text { Expected } \\
\text { sign }\end{array}$ \\
\hline \multirow{4}{*}{8} & $\begin{array}{l}M W_{i t} \\
X_{i t}\end{array}$ & $\begin{array}{l}\text { Minimum wage } \\
\text { Set of control variables comprising of }\end{array}$ & Negative \\
\hline & Age & Continuous variable and refers to number of years of the individual & Positive \\
\hline & Agesquare & Reflects experience and shows relationship between age and wage & Positive \\
\hline & Marital & Indicates whether the worker is married, single or one parent (which includes & Negative \\
\hline \multirow{4}{*}{$\begin{array}{l}\text { Table } 1 \text {. } \\
\text { Description of the } \\
\text { variables }\end{array}$} & $\begin{array}{l}\text { status } \\
\text { Gender }\end{array}$ & $\begin{array}{l}\text { divorced, separated or widowed) } \\
\text { Denotes gender of the individual and takes the value of } 1 \text { if the worker is male } \\
\text { and } 0 \text { if female }\end{array}$ & \\
\hline & Education & $\begin{array}{l}\text { Captures the actual years of schooling, which pertains to whether the } \\
\text { individual has primary education or primary and secondary education, or } \\
\text { primary, secondary and tertiary education. The level of acquired education is } \\
\text { as per the national standard classification of education (NSCED-97) }\end{array}$ & Positive \\
\hline & Urban area & $\begin{array}{l}\text { Refers to town and rural areas relates to the villages and if the individual } \\
\text { resides in town, it takes the value of } 1 \text { and } 0 \text { if it is in rural }\end{array}$ & Positive \\
\hline & \multicolumn{2}{|c|}{ Source(s): Authors' Compilation } & \\
\hline
\end{tabular}

Table 2.

Mean of key variables before and after introduction of minimum wage

\begin{tabular}{|c|c|c|c|c|}
\hline \multirow[b]{2}{*}{ Variables } & \multicolumn{2}{|c|}{ Before introduction of minimum wage } & \multicolumn{2}{|c|}{ After introduction of minimum wage } \\
\hline & Treatment group & Control group & Treatment group & Control group \\
\hline Employed & $0.889(0.314)$ & $0.400(0.490)$ & $0.403(0.491)$ & $0.491(0.500)$ \\
\hline Age & $43.538(15.249)$ & $36.782(22.076)$ & $38.472(27.748)$ & $38.109(20.910)$ \\
\hline Agesquare & $2,127.22(1,371.54)$ & $1,839.93(1,785.52)$ & $1,997.31(1,833.30)$ & $\begin{array}{l}1,889.338 \\
1,715.764\end{array}$ \\
\hline Gender & $0.473(0.500)$ & $0.525(0.500)$ & $0.475(0.500)$ & $0.535(0.499)$ \\
\hline Married & $0.618(0.487)$ & $0.460(0.499)$ & $0.446(0.497)$ & $0.480(0.500)$ \\
\hline One parent & $0.164(0.371)$ & $0.099(0.298)$ & $0.145(0.352)$ & $0.097(0.300)$ \\
\hline Single & $0.218(0.413)$ & $0.442(0.497)$ & $0.377(0.484)$ & $0.406(0.491)$ \\
\hline $\begin{array}{l}\text { Basic primary } \\
\text { education }\end{array}$ & $0.145(00.352)$ & $0.139(0.346)$ & $0.150(0.357)$ & $0.115(0.319)$ \\
\hline $\begin{array}{l}\text { Basic secondary } \\
\text { education }\end{array}$ & $0.259(0.439)$ & $0.230(0.421)$ & $0.246(0.431)$ & $0.226(0.418)$ \\
\hline Prevocational & $0.050(0.217)$ & $0.033(0.179)$ & $0.035(0.184)$ & $0.0403(0.197)$ \\
\hline $\begin{array}{l}\text { Post-secondary } \\
\text { education }\end{array}$ & $0.046(0.209)$ & $0.077(0.267)$ & $0.087(0.282)$ & $0.113(0.317)$ \\
\hline Degree & $0.015(0.123)$ & $0.066(0.249)$ & $0.04(0.065)$ & $0.057(0.231)$ \\
\hline Masters & $0.004(0.062)$ & $0.013(0.111)$ & $0.001(0.035)$ & $0.014(0.111)$ \\
\hline Urban & $0.214(0.411)$ & $0.238(0.426)$ & $0.222(0.415)$ & $0.240(0.427)$ \\
\hline Number of observations & 262 & 1,510 & 1,652 & 3,664 \\
\hline
\end{tabular}

Source(s): Author's computation from CMPHS data (2017-2019), Statistics Mauritius

Note(s): Standard errors (in brackets) are reported above

the higher minimum wage. Regarding the control variables, there have been minimal changes in the mean.

Table 3 presents the marginal effects of the introduction of minimum wage with control and without control variables, where the dependent variable is the probability of employment following the introduction of the minimum wage. The treatment is a dummy variable coded 1 for the group that receives the treatment, and 0 otherwise, and shows the difference in the two groups before the introduction of the minimum wage. In both regressions, the treatment effect has a positive and statistically significant impact on the probability of employment and 


\begin{tabular}{|c|c|c|c|}
\hline Variable & (1) - without control variables & (2) - with control variables & IVlinimum \\
\hline $\operatorname{DID}\left(\beta_{1}\right)$ & $-0.542(0.026)^{* * *}$ & $-0.525(0.026)^{* * *}$ & employment \\
\hline Treatment $\left(\theta_{i}\right)$ & $0.532(0.016)^{* * * *}$ & $0.627(0.033)^{* * * *}$ & \\
\hline Time $\left(\tau_{t}\right)$ & $0.0914(0.016)^{* * * *}$ & $0.089(0.019) * * *$ & \\
\hline Age & - & $0.085(0.003) * * *$ & \\
\hline Agesquare & - & $-0.001(0.0002) * * *$ & \\
\hline Gender & - & $0.354(0.015) * * *$ & 9 \\
\hline Married & - & $0.133(0.024) * * *$ & \\
\hline Oneparent & - & $0.109(0.036) * * *$ & \\
\hline Basic primary education & - & $-0.089(0.030)^{* * * *}$ & \\
\hline Basic secondary education & - & $-0.038(0.184)^{*}$ & \\
\hline Prevocational & - & $0.062(0.041)$ & \\
\hline Post-secondary education & - & $0.192(0.025)^{* * * *}$ & \\
\hline Degree & - & $0.202(0.034) * * *$ & \\
\hline Masters & - & $0.219(0.078) * * * *$ & \\
\hline Urban & - & $0.054(0.019) * * * *$ & \\
\hline Number of observations & 6,148 & 6,148 & \\
\hline \multicolumn{3}{|c|}{$\begin{array}{l}\text { Source(s): Author's computation from CMPHS data (2017-2019), Statistics Mauritius } \\
\text { Note(s): Marginal effects and standard errors (in brackets) are reported above. *** } 1 \% \text { significance level, } \\
* * 5 \% \text { significance level, } * 10 \% \text { significance level }\end{array}$} & $\begin{array}{l}\text { Marginal effects of } \\
\text { minimum wage on } \\
\text { overall employment }\end{array}$ \\
\hline
\end{tabular}

shows that at the baseline before the minimum wage introduction, the probability of employment in the treatment group is 0.627 greater than the control group. The time variable shows the pure effect of the passage of time in the absence of the actual intervention where the probability of being employed is 0.089 for the control group.

The DiD indicator, which is the main variable of interest, shows that there is a statistically negative relationship between minimum wage and employment. More precisely, the regression results with the control variables show that the probability that the individuals in the treatment group remain employed is 0.525 lower following the introduction of minimum wage than those in the control group and supports the predictions of the neoclassical model embodied in Kawaguchi and Mori (2021). However, it contradicts the findings of Asmal et al. (2018) who noted that minimum wages have a positive effect on employment. The contradictory results can be attributed to the fact that the latter considered various remuneration orders as minimum wages, whereas, in the current paper, the newly introduced national minimum wage as the policy intervention impacting employment levels is adopted. Moreover, the two-stage regression used by Asmal et al. (2018) departs from the DiD technique used in the current study to measure the effect of the national minimum wage on employment. The results in the current study comport with those of other studies on the macroeconomic effects of the introduction of minimum wages in developing countries, Gindling and Terrell (2009) as well as Grau and Landerretche (2011) who observed that higher minimum wages have significant negative effects on the probability of staying employed in developing countries. The negative employment effect can be explained by the fact that there have been structural changes in the Mauritian economy from agricultural to service-based sectors concomitant with various technological innovations increasing the demand for more highly skilled workers, hence reducing demand for low-skilled and less-educated workers.

The age of a person is included as age encapsulates the evolution of preferences of a worker throughout the life cycle; moreover, age reflects potential experience, knowledge and skills (Collet and Legros, 2016). The results in Table 3 show that age has a statistically significant and positive effect on employment, where one additional year increases the probability of staying employed by 0.085 . On the other hand, the agesquare variable has a 
JBSED 3,1

small significant negative impact on employment, indicating a non-linear relationship between age and employment. As workers age, their propensity to opt out of the labor market increased for various reasons, due to health issues, family commitments or retirement. These results accord with predictions of the life cycle models of labor supply. For example, Jia (2014) observed that age has a positive effect, whereas agesquare has a negative effect on employment in China. The results also show that gender matters; more precisely, being male increases the probability of employment by 0.354 compared to being female, reflective of a gender bias.

Marriage conceptualizes the gender roles in society and has a significant impact on the labor force (Ogletree, 2015). The results indicate that marital status has significant positive impact on the probability of staying employed. The marginal effect of a married person remaining employed with the introduction of a minimum wage increases by 0.103 and 0.109 for a single parent. Similarly, Avner and Robert (2007) observe that marital status has a positive effect on employment and wage rates and, hence, increases the probability of remaining employed as there is an increase in marriage-induced gains in hours worked upon entering marriage. Furthermore, the results highlight that, with the introduction of the national minimum wage, the probability that a person with basic primary and secondary education remains employed is reduced by 0.089 and 0.038 , respectively. By contrast, postsecondary and tertiary education have significant positive effects on employment as, with additional years of schooling, the individual becomes more skilled. The results are in line with those of Wang and Khan (2021), who observed that people with higher levels of education were more likely to be employed than those who have less or no education. Structural changes in the Mauritian economy from an agricultural to a service economy have driven the demand for more educated and skilled workers. Moreover, the urban variable is significantly positive, indicating that if a worker lives in towns, the probability of being employed increases by 0.054. Such findings comport with those of Mlatsheni and Ranchhod (2016), who observe that location plays an important role in employment with those living in urban areas are far more likely to be employed.

\subsection{Minimum wage effect male and female employment}

Mauritius is often considered a model of development as there has been substantial progress on social equality and poverty reduction, yet unemployment remains a major challenge (International Monetary Fund, 2020). During the year 2020, the overall unemployment hovered around $6.7 \%$ but evincing a stark gender gap: male unemployment $(4.4 \%)$ paling before female unemployment (10.2\%) (Statistics Mauritius, 2020a). The female labor force participation rate $(46.2 \%)$ substantially trails that for men $(73.1 \%)$. Notwithstanding a rise in female labor force participation since independence, yet the gender gap in the Mauritian labor market remains a major concern (Tandrayen-Ragoobur and Pydayya, 2015; TandrayenRagoobur and Gokulsing, 2021). Gaddis and Ranzani (2020) observed that women shoulder the double burden of paid and unpaid work in terms of vocational overlapping with domestic care responsibilities; this double burden contributes to the low participation of women in the Mauritian labor market. Table 4 presents the marginal effects of the introduction of the minimum wage on employment of men and women aged between 16 and 65 years.

For both sexes, the DiD estimate shows that the introduction of the minimum wage has significant negative effects on employment. Interestingly, the probability that males in the treatment group remain employed is 0.425 lower, following the introduction of minimum wage than for that in the control group and for females; however, that probability registers at just 0.547 lower. The results coincide with those of Suryahadi et al. (2003) and Del Carpio et al. (2015), who noted a negative relationship between minimum wage and female employment in Indonesia. 


\begin{tabular}{|c|c|c|c|}
\hline Variable & Male & Female & 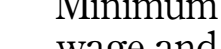 \\
\hline $\mathrm{DID}\left(\beta_{1}\right)$ & $-0.425(0.085)^{* * *}$ & $-0.547(0.038)^{* * * *}$ & mplovment \\
\hline Treatment $\left(\theta_{i}\right)$ & $0.211(0.042)^{* * * *}$ & $0.702(0.040)^{* * * *}$ & \\
\hline $\operatorname{Time}\left(\tau_{t}\right)$ & $0.048(0.023)^{* * *}$ & $0.138(0.027)^{* * * *}$ & \\
\hline Age & $0.074(0.004)^{* * * *}$ & $0.086(0.004)^{* * * *}$ & \\
\hline Agesquare & $-0.001(0.0005)^{* * * *}$ & $-0.001(0.0008)^{* * * *}$ & \\
\hline Married & $0.264(0.029)^{* * * *}$ & $-0.082(0.04)^{* *}$ & \\
\hline Oneparent & $0.113(0.033)^{* *}$ & $-0.067(0.045)^{*}$ & \\
\hline Basic primary education & $-0.129(0.048)^{* * *}$ & $-0.084(0.046)^{*}$ & \\
\hline Basic secondary education & $0.015(0.022)$ & $-0.019(0.028)$ & \\
\hline Prevocational & $0.154(0.023)^{* * *}$ & $-0.141(0.061)^{*}$ & \\
\hline Post-secondary education & $0.045(0.024) * * *$ & $0.271(0.034)^{* * * *}$ & \\
\hline Degree & $-0.009(0.036)$ & $0.308(0.042)^{* * *}$ & \\
\hline Masters & $0.002(0.099)$ & $0.230(0.098)^{* *}$ & \\
\hline Urban & $0.002(0.022)$ & $0.069(0.021)^{* * *}$ & \\
\hline Number of observations & 2,576 & 2,405 & Marginal effects of \\
\hline \multicolumn{3}{|c|}{$\begin{array}{l}\text { Source(s): Author's computation from CMPHS data (2017-2019), Statistics Mauritius } \\
\text { Note(s): Marginal effects and standard errors (in brackets) are reported above. ***1\% significance level, } \\
* * 5 \% \text { significance level, } * 10 \% \text { significance level }\end{array}$} & $\begin{array}{r}\text { minimum wage on } \\
\text { male and female } \\
\text { employment }\end{array}$ \\
\hline
\end{tabular}

Nonetheless, the treatment and time variables show that minimum wages can exert a positive effect on employment. The treatment effect indicates that, prior to the introduction of the minimum wage; the probability of employment of a male in the treatment group is 0.211 greater than the control group, whereas, respectively, it is 0.702 for a female. The time variable is statistically significant irrespective of gender but implies that, in the absence of the minimum wage, the probability of a male being employed is 0.048 , as opposed to 0.138 for a female worker in the control group.

Often viewed as an indicator of a set of skills, knowledge and experience accumulated over the years, age serves as an important driver of labor participation (Barker, 2015). The results show that age has a statistically significant positive effect on employment for both sexes. Interestingly, one year of increase in age enhances the probability that a male worker remains employed by 0.074 , and female worker remains employed by 0.086 . By contrast, the results in this current study show that agesquare has a statistically marginal impact on the probability of remaining employed for both male and female in Mauritius. The results indicate that, while a significant positive effect on continuity in employment accrues for men who are married or who constitute a one-parent family, the opposite manifests for married women for whom a significant negative effect on employment is revealed. Such findings are echoed by Janse van Rensburg et al. (2019), who observed that married women are less likely to be employed, whereas men are more likely to be employed when they are married. Married and single mothers have to shoulder childcare and other unpaid care responsibilities, which often act as an opportunity cost to participate in the labor market. Issues of transportation to and from work, in addition to transport costs involved in seeking work, appear to be more burdensome on female than male workers in as much as the urban variable is significantly positive for female workers, indicating that location variable is important for women.

Educational level is an important factor in income distribution and defines the level of income that an individual receives (Adeosun and Owolabi, 2021). The results indicate that primary education has a significant negative effect on both male and female employment, indicative of the difficulty that a person with only a primary schooling will experience in attempting to find a job. This observation is in line with the findings of Francesconi et al. (2000), who associated higher risks of unemployment with lesser-educated workers. 
JBSED 3,1

Moreover, the human capital theory posits that increasing investment in education stimulates employment opportunities (Chen and $\mathrm{Wu}, 2007$ ) and explains why the Government of Mauritius has invested massively in the education sector with education, compulsory till the age of 16, free from primary to tertiary levels. At the tertiary level, curiously, the impact of the introduction of a minimum wage on male workers is insignificant, while positive and significant on female workers. This might partially be ascribed to "creeping" or derivative glass ceiling effects, in which women may feel compelled to settle for jobs for which they are over-qualified. Alternatively, women may simply be more prone than men to labor market mismatches where the qualifications of the workers do not match job requirements.

\section{Conclusion and policy recommendations}

As the Mauritian government opted to introduce a minimum wage, it presented an excellent opportunity to analyze its effect on employment from a gender perspective in a resource-poor economy dependent on its human capital for its economic prosperity. Derivation of the minimum wage and employment equations proceeded from an elaboration of the theoretical framework of the labor-leisure model of Blundell et al. (2007). Examination of whether (or not) the introduction of minimum wage increases the probability of employment is centered on the utilization of regression equations embedding DiD technique using data drawn from the CMPHS.

Overall, the results are in line with the findings of empirical studies employing the neoclassical model (Andalón and Pagés, 2008; Brown et al., 1983; Neumark and Wascher, 1995b; Suryahadi et al., 2003) where the introduction of the minimum wage reduces employment to a statistically significant extent. Following the introduction of minimum wage, the probability of retaining employment for workers earning less than the minimum wage is 0.525 lower compared to those workers whose salary already exceeded the threshold level. Transformation of the Mauritian economy from an agriculture-predominant to a service-predominant economy most likely served to inflate the "cost" of diminished employment retention incurred with the introduction of the minimum wage in as much as, in a service-predominant economy, a premium is placed on high-skilled workers. Low-skill workers have in effect been "priced out" of the Mauritian economy with the introduction of the minimum wage and structural changes in the economy. The manufacturing sector is a very dynamic and dominant sector in the Mauritian economy, but it faces many challenges such as high cost of labor and lack of trained personnel. However, if the manufacturing sector in the domestic economy would have been more buoyant, in so far as absorbing the increased wage bill afforded by a minimum wage exhibiting, presumably, wage elasticity less than unity, the unemployment effect could have been curbed.

In terms of gender, the negative employment effect is more pronounced among female than male workers. This is explained by the over representation of women in low-paid sectors such as export processing and in pink-collar jobs (Tandrayen-Ragoobur and Pydayya, 2015). Mauritian women also encounter various social and cultural barriers together with household and childcare responsibilities (Gaddis and Ranzani, 2020). These results broadly comport with those of Fang and Lin (2015), who, drawing on a household micro-dataset in China, observed that the minimum wage changes induced significant adverse effects on employment in the Eastern and Central regions of China, with sharp negative employment effects on women and low-skilled workers.

Given the limited presence of complementary policies to support re-integration of women in the labor market, the results imply that the introduction of minimum wage in Mauritius was a setback for erosion of the gender divide. That is particularly evident in comparing male/female employment retention rates in married and one-parent households after minimum wage introduction: $0.264 / 0.082$ and $0.113 / 0.067$, respectively. 
Aberrantly, the minimum wage, however, well intentioned, backfired in terms of its originally set objectives revolving around the protection of employment and the raising of the standard of living of the lowest paid workers. Before the introduction of the minimum wage, it would have behooved the Mauritian government to have skilled up lower-educated workers given that, relative to their more educated cohorts, the incremental probability of workers with only a primary school and secondary school level losing their jobs stands at 0.089 and 0.038 , respectively. In effect, this case study on the introduction of the minimum wage in Mauritius is a cautionary tale for similarly structured economies, with pronounced service sectors but miniscule manufacturing sectors. A gender-sensitive approach to the effects of minimum wage must be adopted by the authorities to ensure that there is equal participation of men and women in the workforce, and as such, reduce the vulnerability of women to loss of employment.

A better way to foster increases in wage rates would revolve around skilling-up, through vocational training, low-skilled and less-educated workers so that market forces work to increase wage rates to attract more productive workers. Strategies must be geared toward the promotion and monitoring of equal access to such training programs for both women and men so as to ensure that both sexes benefit from equality of opportunities in entering the labor market. In addition, skilling-up can also be fostered by increasing the mandatory number of years of schooling, above 16 years of age, given that, for increase in age, the incremental probability of remaining employed is 0.074 for male workers and 0.086 for female workers.

Of course, that the current paper focuses on the short-term impact on employment in Mauritius after the introduction of the minimum wage using data drawn from the years 20172019 opens a further avenue of research, as data become available, on its long-term impact over a more extensive period of time following introduction of the minimum wage. Future research may also pay heed to how the minimum wage may affect non-wage aspects of employment such as hours of work and working conditions. Observing to what extent and how employers offset the effect of minimum wages, for instance, by reducing their non-wage benefits, increase the price of output or by altering the nature of the work are potential research areas to be explored.

\section{References}

Adeosun, O.T. and Owolabi, K.E. (2021), "Gender inequality: determinants and outcomes in Nigeria", Journal of Business and Socio-Economic Development, Vol. 1 No. 2, pp. 165-181.

Ahn, T., Arcidiacono, P. and Wessels, W. (2011), "The distributional impacts of minimum wage increases when both labor supply and labor demand are endogenous", Journal of Business and Economic Statistics, Vol. 29 No. 1, pp. 12-23.

Andalón, M. and Pagés, C. (2008), "Minimum Wages in Kenya", IZA Discussion Papers 3390, IZA Institute of Labor Economics, Bonn.

Asmal, Z., Bhorat, H., Kanbur, R., Ranzani, M. and Paci, P. (2018), "Minimum wages and labor supply in an emerging market -the case of Mauritius", Policy Research Working Paper 8681, World Bank, Washington, DC.

Avner, A. and Robert, I.L. (2007), "How do marital status, work effort, and wage rates interact?", Demography, Vol. 44 No. 3, pp. 623-647.

Barker, F. (2015), The South African Labour Market Theory and Practice, Van Schaik Publishers.

Basu, K. and Felkey, A.J. (2009), "A theory of efficiency wage with multiple unemployment equilibria: how a higher minimum wage law can curb unemployment", Oxford Economic Papers, Vol. 61 No. 3, pp. 494-516. 
JBSED

3,1

Bhorat, H., Kanbur, R. and Stanwix, B. (2014), "Estimating the impact of minimum wages on employment, wages, and non-wage benefits: the case of agriculture in South Africa", American Journal of Agricultural Economics, Vol. 96 No. 5, pp. 1402-1419.

Blundell, R., Chiappori, P.A., Magnac, T. and Meghir, C. (2007), "Collective labour supply: heterogeneity and non-participation”, Review of Economic Studies, Vol. 74 No. 1, pp. 417-445.

Bonin, H., Isphording, I., Krause-Pilatus, A., Lichter, A., Pestel, N. and Rinne, U. (2019), "The German Statutory Minimum Wage and its effects on regional employment and unemployment", IZA Policy Paper 145, IZA Institute of Labor Economics, Bonn.

Brown, C., Gilroy, C. and Kohen, A. (1983), "Time-series evidence of the effect of the minimum wage on youth employment and unemployment”, The Journal of Human Resources, Vol. 18 No. 1, pp. 3-31.

Burdett, K. and Mortensen, D. (1998), "Wage differentials, employer size, and unemployment", International Economic Review, Vol. 39 No. 2, pp. 257-273.

Caliendoa, M., Fedorets, A., Preuss, M., Schröder, C. and Wittbrodte, L. (2018), "The short-run employment effects of the German minimum wage reform”, Labour Economics, Vol. 53 No. 1, pp. 46-62.

Card, D. (1992), "Do minimum wages reduce employment? A case study of California, 1987-89", Industrial and Labor Relations Review, Vol. 46 No. 1, pp. 38-54.

Card, D. and Krueguer, A.B. (1994), "Minimum wages and employment: a case study of the fast-food industry in New Jersey and Pennsylvania”, The American Economic Review, Vol. 84 No. 4, pp. $772-793$.

Carter, C. (1978), “The new minimum wage: a threat to southeastern jobs?”, Economic Review (Federal Reserve Bank of Atlanta), Vol. 63 No. 2, pp. 30-34.

Chen, Z. and $\mathrm{Wu}, \mathrm{Y}$. (2007), "The relationship between education and employment: a theoretical analysis and empirical test", Frontiers of Economics in China, Vol. 2 No. 1, pp. 187-211.

Clemens, J. and Wither, M. (2019), "The minimum wage and the Great Recession: evidence of effects on the employment and income trajectories of low-skilled workers", Journal of Public Economics, Vol. 170 No. 1, pp. 53-67.

Collet, R. and Legros, D. (2016), "Dynamics of female labour force participation in France", Applied Economics, Taylor \& Francis Journals, Vol. 48 No. 30, pp. 2807-2821.

Del Carpio, X., Nguyen, H., Pabon, L. and Wang, L. (2015), "Do minimum wages affect employment? Evidence from the manufacturing sector in Indonesia", IZA Journal of Labor and Development, Vol. 4 No. 17, pp. 1-30.

Fang, T. and Lin, C. (2015), "Minimum wages and employment in China", IZA Journal of Labor Policy, Vol. 4 No. 22, pp. 1-30.

Francesconi, M., Orszag, J., Phelps, E. and Zoega, G. (2000), "Education and the natural rate of unemployment", Oxford Economic Papers, Vol. 52 No. 1, pp. 204-223.

Gaddis, I. and Ranzani, M. (2020), "Fostering labor force participation among Mauritian women quantitative and qualitative evidence", Working paper, Report 149812, World Bank, Washington, DC.

Gindling, T.H. and Terrell, K. (2009), "Minimum wages, wages and employment in various sectors in Honduras", Labour Economics, Vol. 16 No. 3, pp. 291-303.

Grau, N. and Landerretche, O. (2011), "The labor impact of minimum wages: a method for estimating the effect in emerging economies using Chilean panel data", Working Papers wp329, Department of Economics, University of Chile, Chile.

International Monetary Fund (2020), "World economic outlook: a long and difficult ascent", Occasional paper, Surveys Weaf, International Monetary Fund, Washington, DC.

Janse van Rensburg, C.C., Claassen, C. and Fourie, A. (2019), "The relationship between marital status and employment in South Africa", Journal of Economic and Financial Sciences, Vol. 12 No. 1, pp. 1-9. 
Jia, P. (2014), "Employment and working hour effects of minimum wage increase: evidence from China", China and World Economy, Vol. 22 No. 1, pp. 61-80.

Katz, L.F. and Krueger, A.B. (1992), "The effect of the minimum wage on the fast-food industry", Industrial and Labor Relations Review, Vol. 46 No. 1, pp. 6-21.

Kawaguchi, D. and Mori, Y. (2021), "Estimating the effects of the minimum wage using the introduction of indexation", Journal of Economic Behavior and Organization, Vol. 184 No. 1, pp. 388-408.

Machin, S., Manning, A. and Rahman, L. (2003), "Where the minimum wage bites hard : the introduction of the UK national minimum wage to a low wage sector", Journal of the European Economic Association, Vol. 1 No. 1, pp. 154-180.

Mlatsheni, C. and Ranchhod, V. (2016), Migration and Transitions into and Out of Work for Youth, Presentation at REDI $3 X 3$ Youth Unemployment Dialogue, Cape Town.

National Wage Consultative Council (2017), "Introduction of a national minimum wage for the republic of Mauritius", in Council, N.W.C. (Ed.), Republic of Mauritius.

Neumark, D. and Corella, L.F.M. (2020), "Do minimum wages reduce employment in developing countries? A survey and exploration of conflicting evidence", World Development, Vol. 137 (2021) 105165, pp. 1-23.

Neumark, D. and Wascher, W. (1995a), The Effect of New Jersey's Minimum Wage Increase on FastFood Employment: A Re-evaluation Using Payroll Records, NBER Working Paper 5224, National Bureau of Economic Research, Cambridge, MA.

Neumark, D. and Wascher, W. (1995b), The Effects of Minimum Wages on Teenage Employment and Enrolment: Evidence from Matched CPS Surveys, NBER Working Paper 5092, National Bureau of Economic Research, Cambridge, MA.

Ogletree, S.M. (2015), "Gender role attitudes and expectations for marriage", Journal of Research on Women and Gender, Vol. 5 No. 1, pp. 71-82.

Rebitzer, J.B. and Taylor, L.J. (1995), "Efficiency wages and employment rents: the employer-size wage effect in the job market for lawyers", Journal of Labor Economics, Vol. 13 No. 4, pp. 678-708.

Schmitt, J. (2013), Why does the Minimum Wage have no Discernible Effect on Employment?, Center for Economic and Policy Research, Washington, DC.

Schmitz, S. (2017), The Effects of Germany's New Minimum Wage on Employment and Welfare Dependency, Discussion Papers 2017/21, Free University Berlin, School of Business \& Economics.

Statistics Mauritius (2018), "Household budget survey 2017", in Survey, H.B. (Ed.), Mauritius: Statistics Mauritius.

Statistics Mauritius (2020a), "Digest of labour Statistics 2019”, in Labour (Ed.), Mauritius Statistics Mauritius.

Statistics Mauritius (2020b), “Gender Statistics 2019”, in Gender (Ed.), Mauritius: Statistics Mauritius.

Stewart, M.B. (2004), “The employment effects of the national minimum wage”, The Economic Journal, Vol. 114 Conference Papers No. 494, pp. C110-C116.

Sturn, S. (2018), "Do minimum wages lead to job losses? Evidence from OECD countries on Lowskilled and youth employment", Industrial and Labor Relations Review, Vol. 71 No. 3, pp. 647-675.

Suryahadi, A., Widyanti, W., Perwira, D. and Sumarto, S. (2003), "Minimum wage policy and its impact on employment in the urban formal sector", Bulletin of Indonesian Economic Studies, Vol. 39 No. 1, pp. 29-50.

Tandrayen-Ragoobur, V. and Gokulsing, D. (2021), "Gender gap in STEM education and career choices: what matters?", Journal of Applied Research in Higher Education, Vol. ahead-of-print (No. ahead-of-print). 
JBSED 3,1
Tandrayen-Ragoobur, V. and Pydayya, R. (2015), "Glass ceiling and sticky floors: hurdles for Mauritian working women”, Equality, Diversity and Inclusion: An International Journal, Vol. 34 No. 5 , pp. 452-466.

Walsh, F. (2012), "Efficiency wages and bargaining", Oxford Economic Papers, Vol. 64 No. 4, pp. 635-654.

Wang, J. and Gunderson, M. (2018), "Minimum wages effects on low-skilled workers in less developed regions of China”, International Journal of Manpower, Vol. 39 No. 3, pp. 455-467.

Wang, Y. and Khan, S. (2021), "A cross-sectional analysis of employment returns to education and health status in China: moderating role of gender", Frontiers in Psychology, Vol. 12 No. 638599, pp. 1-11.

World Bank (2020), "Doing business 2020", in Bank, W. (Ed.), Doing Business Report, World Bank, Washington, DC.

Zucker, A. (1973), "Minimum wages and the long-run elasticity of demand for low-wage labor", The Quarterly Journal of Economics, Vol. 87 No. 2, pp. 267-277.

\section{Corresponding author}

Varuna Dreepaul-Dabee can be contacted at: varuna1208@gmail.com

For instructions on how to order reprints of this article, please visit our website: 